\title{
Effect of Planting Date on the Growth, Fibre and Seed Yield of Kenaf (Hibiscus cannabinus L) in Ibadan, South Western Nigeria
}

\author{
${ }^{1}$ OLANIPEKUN, SO; ${ }^{2}$ TOGUN, AO
}

\author{
${ }^{I}$ Institute of Agricultural Research and Training (IAR\&T) Moor plantation, Ibadan, Nigeria \\ ${ }^{2}$ Department of Crop Protection and Environmental Biology, University of Ibadan, Nigeria \\ *Corresponding author: olanipekunsam@yahoo.com; Tel: +2348060372347
}

\begin{abstract}
Planting of kenaf usually commences from March - April as these months mark the onset of the rainy season in Nigeria. On the contrary, it is now difficult for anyone to predict when rain start due to climatic variation. Hence, field experiments was conducted between 2015 and 2016 to determine the appropriate time of sowing kenaf that will optimize its yield potential in South Western Nigeria. As a result of delay in the commencement of rain, planting did not start until May. Hence, kenaf seeds were sown in May, June, July and August at 30 days interval in each year. The experiment was a $4 \times 2$ factorial laid out in a randomized complete block design and replicated three times. The result indicated that the highest fibre yield $(1.00 \mathrm{t} / \mathrm{ha})$ was from the kenaf sown in June irrespective of the year, but not significantly different from the one sown in July $(0.98 \mathrm{t} / \mathrm{ha})$. On the other hand, kenaf sown in July had the highest seed yield (2.28 t/ha) with the lowest seed yield (1.04 t/ha) obtained in May followed by August (1.19 t/ha). The experiment conclusively affirm June for sowing of kenaf for fibre cultivation and July for seed production.
\end{abstract}

\section{DOI: https://dx.doi.org/10.4314/jasem.v24i10.2}

Copyright: Copyright (C) 2020 Olanipekun and Togun. This is an open access article distributed under the Creative Commons Attribution License (CCL), which permits unrestricted use, distribution, and reproduction in any medium, provided the original work is properly cited.

Dates: Received: 30 August 2020; Revised: 26 September 2020; Accepted: 17 October 2020

Keywords: Planting date, kenaf, fibre and seed yield

Cultivation of Kenaf (Hibiscuss cannabinus L), is receiving increased attention as a source of paper pulp. Kenaf is a member of the Malvaceae family, native to Africa (Ogunniyan, 2016). It is a multipurpose annual herbaceous plant cultivated for its bast fibre (Danalatos and Archontoulis, 2004). Lam et al. (2003), observed that kenaf fixes about twice the amount of carbon dioxide when compared to forest plantation thereby contributing to alleviation of global warming. It is a short - day photoperiodic fibre plant which grows fast and well adapted for pulp production (Manzanares et al, 1997). On one hand, the short-day flowering characteristic is advantageous, because plants will remain vegetative during the growing season and will produce maximum yields. On the other hand, this characteristic is disadvantageous for seed production.

Flowering in kenaf is attained at a particular period in the year due to photosensitive nature of the crop (Gray et al., 2006). The choice of planting date is very important option in orderto take maximum advantage of the factor of weather and other environmental factors (Brown and Riesberg, 2005). Planting seed when the air temperature is high could aid uniformity in the emergence of seedlings (Danalatos and Archontoulis, 2010). Inappropriate planting date aids premature flowering and reduction in yield (Danalatos and Archontoulis, 2010), For instance, planting too early could lead to poor and non-homogeneous seedling emergence and growth impairment. whereas, planting too late may affect growth performance, biomass and seed yields as a result of reduction in the available time for growth and little solar radiation for photosynthetic activity and other unfavorable growth condition (Cosentino et al., 2004; Gray et al., 2006). It has been reported that kenaf production may drop to $40 \%$ or less due to unfavourable condition (Danalatos and Archontoulis, 2010). However to attain high biomass production of kenaf, appropriate planting time must be ensured. In the time past, cultivation of kenaf in Nigeria has been scheduled for March to April for fibre production and August $1^{\text {st }}$ to 15 th for seed production (IAR\&T, 2015).

This, however, has been distorted by unpredictable rainfall (amount and distribution), prolonged and unpredictable dry spell during the growing season with attendant low yields. Hence, the need to reassess the choice of planting date of this photosensitive plant, to ensure the efficient utilization of all other inputs for optimum yield. The objective of this study was to determine the appropriate time of sowing kenaf for optimum yield in Ibadan south western Nigeria. 


\section{MATERIALS AND METHODS}

Site description: The experimental field was located within the rain forest-savanna transition agroecological zone of Nigeria. The ecology is characterized with bimodal rainfall distribution with distinct dry and wet seasons. Annual rainfall was between 1084 and $1249 \mathrm{~mm}$ for the year 2015 and 2016 respectively. The dry season ran through early November to the end of March, while the raining season falls within the month of April to October of each year. Average sun shine hour in the year 2015 was 7 hours while it was 6.8 hours in 2016. Annual maximum temperature was $30 \pm 5{ }^{\circ} \mathrm{C}$. Relative humidity was high during the period of the field trials and was between 64 and $89 \%$ within the period of the experiment. Information on rainfall and other weather parameters for the period of the experiment was collected from the Nigerian Meteorological Agency (Table 1).

Table 1: Recorded weather parameters for 2015 and 2016 experimental seasons.

\begin{tabular}{|c|c|c|c|c|c|c|c|c|c|c|c|c|c|c|}
\hline & $\mathrm{J}$ & $\mathbf{F}$ & $\mathbf{M}$ & A & $\mathbf{M}$ & $\mathrm{J}$ & $\mathrm{J}$ & A & $\mathrm{S}$ & $\mathbf{0}$ & $\mathbf{N}$ & D & $\begin{array}{l}\text { Total } \\
\text { rainfall } \\
(\mathrm{mm})\end{array}$ & $\begin{array}{l}\text { Rainy } \\
\text { day }\end{array}$ \\
\hline \multicolumn{15}{|l|}{2015} \\
\hline Total rainfall (mm) & 5 & 15 & 44 & 144 & 164 & 192 & 153 & 146 & 197 & 168 & 19 & 2 & 1249 & 222 \\
\hline Max Temp (C) & 33 & 34 & 33 & 33 & 33 & 32 & 30 & 29 & 29 & 30 & 33 & 33 & & \\
\hline Min Temp ( $\mathrm{C}$ ) & 20 & 23 & 22 & 21 & 20 & 20 & 21 & 22 & 21 & 21 & 22 & 20 & & \\
\hline Sunshine Hour(hr/day) & 7.4 & 7 & 7 & 7 & 7.6 & 7 & 7 & 7.8 & 7 & 6.8 & 7 & 7 & & \\
\hline R. Humidity (\%) & 69 & 48 & 74 & 79 & 64 & 79 & 74 & 64 & 89 & 55 & 39 & 56 & & \\
\hline \multicolumn{15}{|l|}{2016} \\
\hline Total rainfall (mm) & 7 & 14 & 56 & 159 & 151 & 198 & 166 & 144 & 189 & 161 & 12 & 0 & 1084 & 250 \\
\hline Max Temp (C) & 34 & 34 & 34 & 34 & 33 & 31 & 29 & 30 & 31 & 32 & 34 & 34 & & \\
\hline Min Temp ( $\left.{ }^{0} \mathrm{C}\right)$ & 21 & 22 & 23 & 22 & 21 & 20 & 22 & 23 & 20 & 21 & 21 & 21 & & \\
\hline Sunshine Hour(hr/day) & 7 & 7.3 & 7.8 & 7 & 6.8 & 7.4 & 6.6 & 6.8 & 7 & 7 & 7.2 & 7.2 & & \\
\hline R. Humidity (\%) & 62 & 65 & 79 & 72 & 89 & 88 & 82 & 80 & 86 & 64 & 54 & 48 & & \\
\hline
\end{tabular}

Source: Nigerian Meterological Agency $(2013-2016)$; Ave $=$ Average, Max. $=$ maximum, Min. $=$ minimum and R= relative humidity

Field work: A two year experiment was carried out in at the experimental farm of the Institute of Agricultural Research and Training, located within rainforest savanna transition zone (07038'N, 03084'E $182 \mathrm{~m}$ ) Ibadan, Oyo States, Nigeria. The field was ploughed; harrowed and marked out accordingly to fit into the randomized complete block designed (RCBD) with three replicates. Kenaf seed (Ifeken 100 variety) was sown at 30 days interval beginning from the month of May, followed by June, July and August respectively in 2015 and 2016 at a spacing of $0.2 \mathrm{~m} \times$ $0.5 \mathrm{~m}$ with two plants per stand $(360,000$ plant/ha $)$. Weeding was done twice 3 and 6 weeks after planting (WAP) in each month while insect pests were controlled at 4 and 8 WAP using Laraforce (Lambda cyhalothrin $2.5 \%$ E.C) at the rate of $1 \mathrm{~L} /$ ha with dilution factor of $2.5 \mathrm{ml} / \mathrm{litre}$.

Data collection and analysis: Five plants were randomly selected from each plot for data collection at 4, 6, 8, 10 and 12 weeks after sowing (WAS) on plant height, stem diameter and number of leaves. At 10 WAS, plants were cut from each plot to determine the fibre yield. The plants were retted in water for 14 days and thereafter separated into bast and core, and were washed, sundried and weighted. At 20 WAS, seed were harvested and threshed to separate the seed from the capsule. The seed were weighed on plot basis. All data were subjected to analysis of variance (ANOVA) while the means were compared using Duncan
Multiple Range Test (DMRT) at $P \leq 0.05$. Data on weather parameters for the experimental years were sourced from Nigerian Meterological Agency.

\section{RESULT AND DISCUSSION}

Effect of sowing date on plant height, stem diameter and number of leaves of kenaf: Sowing date significantly affected the vegetative growth and development of kenaf. Plant height, stem diameter and number of leaves generally increased from 4 to 12 WAS at each planting date (Table 2). Plant heights $(52.52 \mathrm{~cm})$ at 4 WAS, $(94.21 \mathrm{~cm})$ at 6 WAS and $(146.07 \mathrm{~cm})$ at $8 \mathrm{WAS}$ for kenaf sown in May were not significantly different from $(52.14 \mathrm{~cm})$ at 4 WAS, $(98.42 \mathrm{~cm})$ at $6 \mathrm{WAS}$ and $(151.86 \mathrm{~cm})$ at 8 WAS respectively, for krnaf sown in June. However, plant heights at 10 and 12 WAS (200.22 and $262.83 \mathrm{~cm}$, respectively) for kenaf sown in June were significantly higher than those sown in May at the respective weeks after sowing (Table 2). The least plant height (133.70 $\mathrm{cm})$ at harvest was obtained from kenaf sown in August. Plant height was consistent in both years, though plant height was significantly higher (241.43 $\mathrm{cm})$ in 2015 than in $2016(219.19 \mathrm{~cm})$ at $12 \mathrm{WAS}$. The stem diameters $(0.71$ and $1.49 \mathrm{~cm})$ at 4 and 6 WAS for kenaf sown in May were significantly higher than those planted in other months at similar WAS. Stem diameters in 2015 and 2016 increased in the order of kenaf sown in May $>$ kenaf sown in June $>$ kenaf sown in July $>$ kenaf sown in August. However, stem 
diameters from kenaf sown in May, June, and July were not significantly different from one another at 8 , 10 and 12 WAS while it was least $(0.71,0.96$ and 1.19 cm respectively) from kenaf sown in August at similar WAS. The number of leaves obtained from kenaf sown in May was significantly higher at 4, 6, 8, 10 and 12 WAS than those sown in June and July while those sown in August had the least leave number during the same period. Similar trend was observed in 2015 and
2016 (Table 2). The plant height and stem diameter which are indicators for fibre yield declined as sowing date advances from May. Danalatos and Archontoulis, (2004) in his report from a research done at western Thessaly, central Greece suggested the month of May as an ideal date for sowing kenaf when the soil temperature exceeds $15^{\circ} \mathrm{C}$. Similarly, the results showed that kenaf sown in June were more vegetative than those sown in other months.

Table 2: Effect of sowing date on the vegetative growth of kenaf cultivated at Ibadan in 2015 and 2016

\begin{tabular}{|c|c|c|c|c|c|c|c|c|c|c|c|c|c|c|c|}
\hline \multirow{2}{*}{$\begin{array}{l}\text { Sowing } \\
\text { date }\end{array}$} & \multicolumn{5}{|c|}{ Plant height (cm } & \multicolumn{5}{|c|}{$\begin{array}{l}\text { Stem diameter }(\mathrm{cm}) \\
\text { Weeks After Sowing }\end{array}$} & \multicolumn{5}{|c|}{ Number of leaves } \\
\hline & 4 & 6 & 8 & 10 & 12 & 4 & 6 & 8 & 10 & 12 & 4 & 6 & 8 & 10 & 12 \\
\hline May & $52.52^{a}$ & $94.21^{a}$ & $146.07^{1}$ & $173.08^{\circ}$ & $244.05^{\circ}$ & $0.71^{2}$ & $1.49^{2}$ & $1.78^{2}$ & $1.95^{2}$ & $2.32^{2}$ & $22.57^{2}$ & $45.03^{2}$ & $64.21^{2}$ & 75.96 & $98.80^{25}$ \\
\hline June & $52.14^{a}$ & $98.42^{a}$ & $151.86^{a}$ & $200.22^{2}$ & $262.83^{2}$ & $0.64^{\mathrm{b}}$ & $1.23^{\mathrm{b}}$ & $1.58^{2}$ & $1.84^{\mathrm{a}}$ & $2.14^{2}$ & $13.51^{\mathrm{b}}$ & $20.59^{\prime}$ & $35.19^{x}$ & $67.29^{\circ}$ & $80.40^{b}$ \\
\hline July & 36.16 & $76.65^{b}$ & $130.72^{b}$ & $160.17^{\circ}$ & $240.57^{\circ}$ & $0.42^{i}$ & $0.84^{i}$ & $1.35^{\mathrm{a}}$ & $1.74^{2}$ & $1.99^{\circ}$ & $10.80^{b x}$ & $20.90^{b}$ & $45.06^{b}$ & $55.20^{b}$ & $76.12^{b}$ \\
\hline $\begin{array}{l}\text { August } \\
\text { Year }\end{array}$ & 28.17 & $50.07^{2}$ & $84.79^{\circ}$ & $133.70^{c}$ & $173.79^{\circ}$ & $0.41^{c}$ & $0.46^{4}$ & $0.71^{\mathrm{b}}$ & $0.96^{\mathrm{b}}$ & $1.19^{h}$ & $8.04^{\circ}$ & $8.12^{\circ}$ & $22.32^{c}$ & $35.10^{c}$ & $44.01^{c}$ \\
\hline 2015 & $42.38^{a}$ & $83.78^{a}$ & $137.42^{2}$ & $165.12^{2}$ & $241.43^{2}$ & $0.57^{2}$ & $1.04^{2}$ & $1.46^{\circ}$ & $2.53^{4}$ & $2.12^{2}$ & $14.63^{\mathrm{a}}$ & $25.33^{a}$ & $38.75^{a}$ & $57.53^{a}$ & $87.12^{*}$ \\
\hline 2016 & $42.11^{a}$ & $75.89^{\circ}$ & $119.30^{\circ}$ & $168.47^{2}$ & $219.19^{\circ}$ & $0.52^{2}$ & $0.91^{\mathrm{b}}$ & $1.24^{\mathrm{b}}$ & $1.57^{\mathrm{h}}$ & $1.71^{\mathrm{b}}$ & $12.83^{*}$ & $21.99^{\circ}$ & $44.64^{2}$ & $54.25^{a}$ & $62.55^{\mathrm{b}}$ \\
\hline
\end{tabular}

Effect of sowing date on the fibre and seed yield of kenaf: Time of sowing significantly influenced bast, core fibre and seed yield. The bast yield (fig.1) in May (0.84 t/ha), June (0.99 t/ha) and July (0.91 t/ha) were not significantly different at $(P<0.05)$ but were all significantly higher than $0.32 \mathrm{t} /$ ha obtained in August. The core yields (1.37 and $1.88 \mathrm{t} / \mathrm{ha}$ ) in May and June respectively were significantly higher.

The highest core yield (2.52 t/ha) was obtained in July but not significantly different from the core yield in June (1.88 t/ha) but the yield was significantly higher than those of May and August. However, the least core yield (0.69 t/ha) was obtained in August and differed significantly from other months.

Highest seed yield (2.28 t/ha) was obtained from kenaf sown in July, followed by seed yield (1.73 t/ha) obtained from the one sown in June while the lowest $(1.04 \mathrm{t} / \mathrm{ha})$ was from kenaf sown in May which however not significantly different from (1.19 t/ha) obtained in August (fig. 3).

Planting could not be done earlier than May as a result of delay in the onset of rain and result indicated that kenaf sown in August has low fibre and seed yield, this may be connected to unfavourable climatic condition (Fernado et al., 2004) and this could hamper its development and yield. This study revealed that kenaf could be sown in May, June or July for fibre yield while July is most appropriate for seed production in south western part of Nigeria.

The result showed that August is not appropriate for kenaf cultivation either for fibre or seed production.
This agreed with the report of Alexopoulou et al (2004), who reported that early sowing favoured growth and fibre yield of kenaf than late planting except with irrigation. Sowing date has a direct effect on the growth and yields of kenaf.

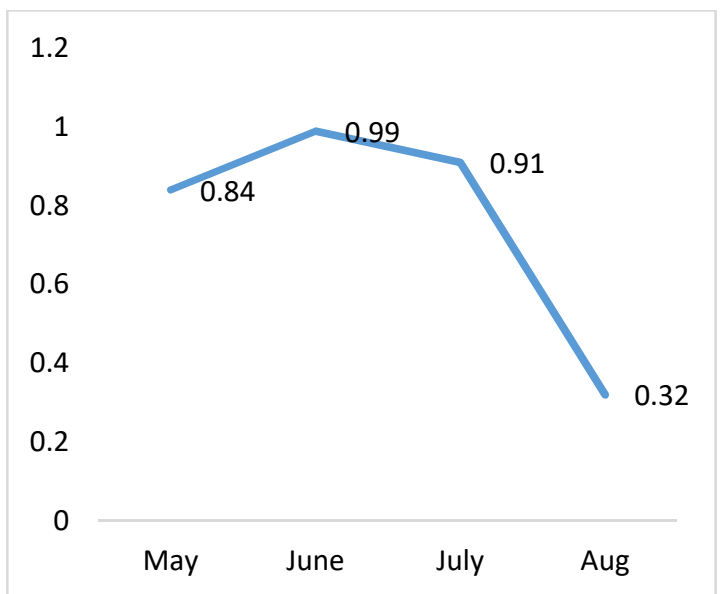

Fig 1: Bast yield ( $\mathrm{t} / \mathrm{ha}$ ) per months of sowing, means separated using DMRT at $P \leq 5 \%$

The variation in climatic conditions, especially the sunshine hour and rainfall pattern strongly influence the differences in kenaf performance in terms of growth, fibre and seed yield. It was evident from the results that poor solar radiation and unbalanced rainfall pattern probably accounted for reduction recorded in the growth of kenaf in the month of July and August. This is because too little or too much water at critical stages of growth of kenaf can reduce either fibre or seed yield since adequate moisture availability promotes vegetative growth and seed yield in kenaf (Danalatos and Archontoulis, 2010). 


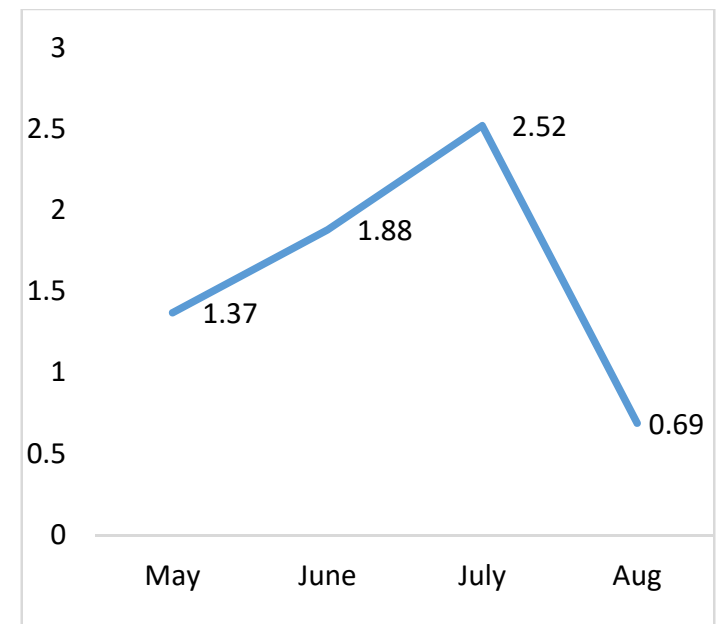

Fig 2: Core yield (t/ha) per months of sowing, means separated using DMRT at $P \leq 5 \%$

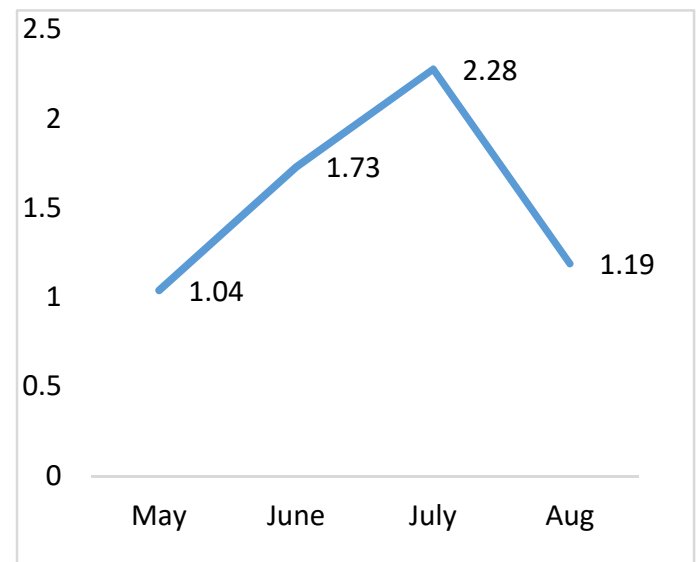

Fig 3: Seed yield (t/ha) per months of sowing, means separated using DMRT at $P \leq 5 \%$

Conclusion: The work conclusively affirm that kenaf plant growth attributes such as stem elongation, diameter and number of leaves were higher from kenaf sown in May, June and July hence, contributed to the fibre and seed yield. May/June is therefore recommended for sowing of kenaf for fibre cultivation and July is most appropriate for seed production in south western Nigeria

\section{REFERENCE}

Brown, A; Riesberg, L (2005). In Abiotic stress. Genetic features of population stress prone environment. In Proceeding of workshop on enhancing the use of genetic diversity to manage abiotic stress in agricultural production systems. Eds 23-27 May 2005 Budapest Hungary: 8-15.

Cosentino, SL; D’Agosta, GM; Copani, V; Testa, G (2004). Yield and development of kenaf (Hibiscus cannabinus L.) crop in relation to genetype, sowing time and plant population in
Mediterranean environment. In: Van Swaalj, W.P.M., Fjalistrom, T., Helm, P., grassi, A. (Ed.), Biomass for Energy, Industry and Climate protection. Proceedings of $2^{\text {nd }}$ World Biomass Conference, 10-14 May, Roma, Italy, pp 381-4.

Danalatos, NG; Archontoulis, SV (2004). Potential growth and biomass productivity of kenaf (Hibiscus cannabinus L.) under central Greek conditions: The influence of fertilization and irrigation. $2^{\text {nd }}$ World Conference on Biomass for energy, industry and Climate protection: 323-326.

Danalatos, NG; Archontoulis, SV (2010). Growth and biomass productivity of kenaf (Hibiscus cannabinus L.) under different agricultural input and management practices in central Greece: 231240: Industrial Crops Products 32: 231-240

Fernando, A; Duarte, P; Morais, J; Catroga, A; Serras, G; Pizza, S; Godovikova, V; Oliveira, JS (2004). Characterization of kenaf potential in Portugal as an industrial and energy feedstock- the effect of different varieties, sowing dates, plant populations and different harvest dates. In: Van Swaalj, W.P.M., Fjalistrom, T., Helm, P., Grassi, A. (Ed.), Biomass for Energy, Industry and Climate Protection. Proceedings of the $2^{\text {nd }}$ World Biomass Conference, 10-14 May, Roma, Italy, pp 281-4.

Gray, LN; Collavino, NG; Simon, GE; Mariotti, JA (2006). Diallelic analysis of genetic effects determining days to flowering in kenaf. Industrial Crops Production, 23: 194-200.

Lam, TB; Tuyet, HK; Iiyama, K (2003). Structural characteristics of cell walls of kenaf (Hibiscus cannabinus L.) and fixation of carbon dioxide $J$. Wood Sci. 49.3: 255 - 261.

Manzanares, M; Tenorio, JI; Ayerbe, L (1997). Sowing time, cultivar, plant population and application of N fertilizer on kenaf Spain's central Plateau. Biomass Bioenergy 14 (4): 263-271

Ogunniyan, DJ (2016). Assessment of genetic divergence in kenaf (Hibiscus cannabinus L) genotypes using agro-botanical characteristics and multivariate analysis. J. Breed. Gene.48 (1): 61-71.

Kenaf Production and Processing, farmers' guide (2015). Publisher: Publication Unit, IAR\&T, Ibadan. 